\title{
Analisa Manajemen Dan Efisiensi Penyediaan Pakan Ayam Pada Poultry Shop
}

\author{
R. Syafriardi, Fitrini, Kamaruzaman
}

Fakultas Peternakan Universitas Andalas Padang

\begin{abstract}
The objectives of this research were to determine the optimum quantity of feed stacked or ordered which gave the most economic efficiency in daily management practices of poultry shop. The case study was conducted at Rajawali poultry shop, located in Lubuk Begalung sub district, Padang city. Data or information collected included: kind of feed stocked; volume and time schedule of feed ordered; procedures and cost of feed ordering. handling, storage and distribution. The data were statistically analyzed by twing Economic Order Quantity Method. The results showed that the poultry shop has applied good stock management practices. The quantity and frequency of feed ordered of 69,784 $\mathrm{kg}$ for every 2 days was fotand the most optimum management practices which might save cost of about Rp, 9,064,874 for the year of 2006 .
\end{abstract}

Keywords: stock management, chicken feed, economic order quantity

\section{Pendahuluan}

Pakan adalah input produksi yang sangat penting dalam usaha peternakan ayam ras petelur. Pakan berupa sediaan dari bahan tanaman pertanian (organik) dengan daya simpan dan ketahanan nilai gizi yang terbatas. Walaupun telah digunakan bahan pengawet, pakan tetap saja bisa mengalami penurunan kandungan gizi karena lamanya penyimpanan. $\mathrm{Ke}$ butuhan pakan di suatu daerah berkaitan dengan besarnya populasi ternak (ayam) di daerah tersebut. Semakin besar populasi ayam maka semakin besar pula jumlah pakan yang dibutuhkan.

Populasi ayam ras di kota Padang memiliki angka kenaikan yang besar setiap tahunnya. Pada Tabel 1 dapat dilihat perkiraan kebutuhan pakan ayam di Sumatera Barat dan Kota Padang untuk 3 tahun kedepan.

Sampai saat ini kota Padang
belum memiliki industri pakan
komersil, oleh karena itu untuk
memenuhi kebutuhan pakan ayam di
Kota Padang maka peranan pengusaha
sebagai penyalur/ distributor pakan
sangat dibutuhkan oleh peternak ayam
di Kota Padang.
Rajawali Feed Center dipilih
sebagai objek penulisan/penelitian,
secara purposive, karena usaha ini
merupakan salah satu distributor
pakan terbesar yang ada di kota
Padang dan juga merupakan agen
resmi perusahaan PT. Charoen
Phokphand Medan. Jenis pakan yang
dijual di Rajawali dapat dilihat pada
Tabel 3. Perusahaan ini memiliki
pasar yang cukup luas, selain di
wilayah Sumatera Barat juga di
provinsi Riau dan Jambi dengan
permintaan yang fluktuatif. Kondisi
ini membawa perusahaan pada dua
resiko, jika persediaan menumpuk
(over stock) maka akan menghadapi
resiko kerugian dan jika persediaan
belum memiliki industri pakan komersil, oleh karena itu untuk memenuhi kebutuhan pakan ayam di Kota Padang maka peranan pengusaha sebagai penyalur/ distributor pakan sangat dibutuhkan oleh peternak ayam di Kota Padang. sebagai objek penulisan/penelitian, secara purposive, karena usaha ini merupakan salah satu distributor pakan terbesar yang ada di kota Padang dan juga merupakan agen resmi perusahaan PT. Charoen Phokphand Medan. Jenis pakan yang dijual di Rajawali dapat dilihat pada Tabel 3. Perusahaan ini memiliki pasar yang cukup luas, selain di provinsi Riau dan Jambi dengan permintaan yang fluktuatif. Kondisi ini membawa perusahaan pada dua resiko, jika persediaan menumpuk (over stock) maka akan menghadapi
resiko kerugian dan jika persediaan 
sedikit (stock out) maka permintaan konsumen tidak dapat terpenuhi.

Penelitian dilakukan dengan tujuan: Untuk mengetahui manajemen persediaan pakan ayam yang dilakukan oleh Rajawali Feed Center. Selain itu juga untuk mengetahui kuantitas pemesanan untuk setiap jenis pakan ayam agar mencapai tingkat pemesanan yang ekonomis dan efisien bagi perusahaan untuk tahun 2006.

\section{Materi Dan Metode}

Penelitian dilakukan dengan melalui studi kasus (case study) pada Rajawali Feed Center. Untuk mendapatkan data tertulis dilakukan konfirmasi kepada bagian-bagian yang melakukan pencatatan berkaitan dengan pengadaan persediaan dalam usaha.

Data diperoleh melalui wawancara dengan pimpinan perusahaan ditambah dari bagian-bagian yang terlibat dalam manajemen persediaan pakan ayam pada usaha tersebut. Data sekunder diperoleh melalui data /laporan tertulis yang dihimpun oleh bagian dalam perusahaan yang melakukan pencatatan berkaitan dengan persediaan pakan ayam dan dari instansi terkait, yaitu Dinas Peternakan (data untuk daerah kota Padang).

Data atau informasi yang dikumpulkan adalah :

1. Proses Pengambilan Keputusan Melakukan Pemesanan Pakan

2. Proses Pemesanan

Tabel 1. Perkiraan Kebutuhan Pakan Ayam di Sumatera Barat

\begin{tabular}{lcccc}
\hline Jenis Ayam & Tahun & $\begin{array}{c}\text { Jumlah Ayam } \\
\text { (ekor) }\end{array}$ & $\begin{array}{c}\text { Kebutuhan Per } \\
\text { Ekor }\end{array}$ & $\begin{array}{c}\text { Perkiraan } \\
\text { Kebutuhan } \\
(\mathrm{kg})\end{array}$ \\
\hline Ayam & 2003 & 10.608 .542 & $1,6 \mathrm{~kg} /$ periode & $16.973 .667,2$ \\
Pedaging & 2004 & 12.804 .118 & $1,6 \mathrm{~kg} /$ periode & $20.486 .588,8$ \\
& 2005 & 11.357 .781 & $1,6 \mathrm{~kg} /$ periode & $18.172 .449,6$ \\
\hline Ayam Petelur & 2003 & 4.706 .628 & $32,85 \mathrm{~kg} /$ tahun & $154.612 .729,8$ \\
& 2004 & 5.337 .255 & $32,85 \mathrm{~kg} /$ tahun & $175.328 .826,8$ \\
& 2005 & 5.608 .482 & $32,85 \mathrm{~kg} /$ tahun & $184,238.633,7$ \\
\hline
\end{tabular}

Tabel 2. Perkiraan Kebutuhan Pakan Ayam di Kota Padang

\begin{tabular}{lcccc}
\hline Jenis Ayam & Tahun & $\begin{array}{c}\text { Jumlah } \\
\text { Ayam } \\
\text { (ekor) }\end{array}$ & $\begin{array}{c}\text { Kebutuhan Per } \\
\text { Ekor }\end{array}$ & $\begin{array}{c}\text { Perkiraan } \\
\text { Kebutuhan } \\
(\mathrm{kg})\end{array}$ \\
\hline Ayam & 2003 & 3.650 .000 & $1,6 \mathrm{~kg} /$ periode & 5.840 .000 \\
Pedaging & 2004 & 4.856 .900 & $1,6 \mathrm{~kg} /$ periode & 7.771 .040 \\
& 2005 & 4.602 .785 & $1,6 \mathrm{~kg} /$ periode & 7.364 .456 \\
\hline Ayam Petelur & 2003 & 400.800 & $32,85 \mathrm{~kg} /$ tahun & 13.166 .280 \\
& 2004 & 516.400 & $32,85 \mathrm{~kg} /$ tahun & 16.963 .740 \\
& 2005 & 539.622 & $32,85 \mathrm{~kg} /$ tahun & $17.726582,7$ \\
\hline
\end{tabular}

Sumber: *) Dinas Peternakan Stumatera Barat dan Kota Padang

*) Rasyaf tahan 1990 (ayam petelur) dan Rasyaf tahun 1999 (ayam pedaging). 
3. Proses Pengiriman Pakan

4. Proses Penanganan Pakan yang Datang

5. Proses Penyimpanan Pakan

6. Proses Distribusi Pakan

Untuk menjawab tujuan pene-

litian yang kedua yaitut tentang kuantitas pemesanan yang ekonomis. variabel yang diamati yaitu :

1. Kebutuhan pakan per tahun

2. Jumlah yang dipesan masingmasing jenis pakan pada setiap pemesanan

3. Periode pemesanan yaitu rentang waktu antara pemesanan pertama dengan pemesanan selanjutnya

4. Biaya pemesanan (ordering costs)

5. Biaya penyimpanan (carrying costs)

6. Harga pakan perunit

7. Lead Time (waktu penyerahan pakan yang dipesan)

Analisis yang dilakukan pada penelitian ini adalah analisis deskriptif kualitatif dan analisis deskriptif kuantitatif. Analisis deskriptif kualitatif menyajikan tentang manajemen persediaan pakan ayam yang dilakukan oleh Rajawali Feed Center. Analisis deskriptif kuantitatif dengan menggunakan konsep Economic Order Quantity $(E O Q)$, tujuannya adalah untuk mengetahui dan menentukan jumlah pemesanan pakan ayam yang ekonomis yang dilakukan oleh pihak distributor.

Assauri (1999) mengemukakan bahwa rumus yang digunakan untuk jumlah optimum unit per order adalah:

$$
N=\sqrt{\frac{2 A P}{R C}}
$$

dimana,

$A=$ jumlah kebutukan pakan ayam per tahun

$\mathrm{R}=$ harga pakan ayam rata-rata per unit

$\mathrm{P}=$ biaya pemesanan
$\mathrm{C}=$ biaya penyimpanan, yang dinyatakan sebagai suatu presentasi dari persediaan ratarata

$\mathrm{N}=$ jumlah pesanan ekonomis Dengan simbol dan notasi diatas, dapatlah ditetapkan bahwa biaya pemesanan per tahun adalah : A $/ N x P$ dan biaya penyimpanan pertahun :

$\frac{A R}{2 \pi} \times 0,5 \times C=R C N / 2$

Sehingga total biaya (TC) adalah :

$T C=4 / N x P+R C N / 2$

Dimana $0,5 \mathrm{RCN}$ atau $\mathrm{RCN} / 2$ merupakan tetapan yang diperoleh dari $N / 2$, yaitu persediaan rata-rata pada tingkat $\mathrm{A} / \mathrm{N}$ (periode pemesanan selama satu tahun).

Handoko (1984) menyatakan bahwa ada beberapa asumsi yang barus dipenuhi yaitu :

1. Permintaan/kebutuhan penjualan pakan ayam adalah konstan, seragam dan diketahui (deterministik) untuk tahun 2006.

2. Harga per unit pakan ayam adalah konstan, rata-rata $\mathrm{Rp} 3.304,7$ per kilogram.

3. Biaya penyimpanan pakan ayam per unit per tahun adalah konstan, yaitu rata-rata $\mathrm{Rp} 15,32$ per $\mathrm{kg}$.

4. Biaya pemesanan per pesanan adalah konstan, yaitu Rp 9.687.110 per pesanan

5. Waktu antara pesanan dilakukan dengan barang-barang diterima (lead time) adalah konstan, ratarata 1 minggu.

Untuk tahun 2006 karena belum terekapitulasinya data perusahaan, maka penulis berupaya melakukan proyeksi. Metode yang digunakan adalah metode Least Square (Assauri, 1999) dengan formulasi sebagai berikut: $\sum Y=n a+b \sum x$ untuk mencari nilai $a$, dan rumus 
$\sum X Y=a \sum X+b \sum X^{2}$ untuk mencari

nilai b. Rumus $Y_{X}=a+b X$ digunakan untuk menentukan sales forcasting. Nilai a dan $b$ adalah konstanta, $X$ adalah periode tahun dan $\mathrm{Y}$ adalah jumlah penjualan pada periode $\mathrm{X}$.

Metode ini dipilih karena dinilai lebih sederhana dan sesuai dengan data yang tersedia, menurut Handoko (1984) least square adalah salah satu metode yang paling luas digunakan untuk menentukan persamaan trend data karena metode ini menghasilkan apa yang secara matematis digambarkan sebagai line of best fit.

\section{Hasil Dan Pembahasan}

\section{A. Gambaran Umum Perusahaan}

Rajawali Feed Centre merupakan salah satu distributor pakan ternak di kota Padang, beralamat di $I$. By Pass No. 5 Lubuk Begalung Padang, berdiri sejak 1 Januari 1996, mulanya hanya sebagai pedagang pengecer mulai tahun 1996 sampai tahun 1999. Tahun 1999 melakukan ekspansi menjadi agen pakan ayam. Pada tahun 2000 resmi menjadi agen dari PT. Charoen Pokphand Medan. Pada tahun 2001 membuka cabang di Payakumbuh yang merupakan daerah peternakan ayam terbanyak di Sumatera Barat. Rajawali Feed Centre memiliki kapasitas penjualan pakan dengan skala yang cukup besar dengan wilayah pemasarannya meliputi Sumatera Barat, Riau dan Jambi. Selain menjual pakan dengan skala besar untuk peternakan ayam, Rajawali juga menjual pakan dengan permintaan skala kecil(eceran).

\section{B. Persediaan Pakan Ayam Rajawali Feed Centre.}

\section{Jenis Persediaan Fisik Pakan}

Bentuk pakan yang dijual di Rajawali terdiri dari tepung (all mash), butiran (pellet), dan butiran pecah (crumble). Pakan yang paling diminati umumnya berbentuk butiran pecah, karena cocok untuk ayam semua umur.

Keterangan jenis pakan di Rajawali sesuai dengan kebutuhan ayam berdasarkan masa pemeliharaannya dapat dilihat pada Tabel 3 .

\section{Sistem Persediaan Pakan}

Persediaan Rajawali berupa fluctution stock. Pengadaan persediaan pakan berdasarkan pemantauan di lapangan dan analisis persedian yang terdapat di gudang. Keputusan persediaan pakan di Rajawali bersifat sediaan independen.

\section{Persediaan Pengaman (Buffer Stock) \\ Di Rajawali, stok penyangga} (buffer stock) terjadi pada saat tertentu saja, yaitu saat lebaran dan tahun baru. Pada dua periode ini, biasanya angkutan tidak beroperasi sehingga perusahaan memesan double stock untuk menanggulangi beberapa hari libur tersebut. Terkadang stok penyangga ini berlaku pada saat harga pakan akan naik sesuai dengan informasi dari pabrik, agar mendapatkan harga yang lebih murah. Stok penyangga dalam setahun terjadi hanya dua kali. Sedangkan untuk kebutuhan harian, tidak menggunakan stok penyangga.

\section{Gudang Penyimpanan Pakan}

Gudang penyimpanan pakan didirikan secara permanen daya tampung lebih dari 150 ton. Selain gudang utama terdapat juga gudang lain dekat kantor dengan daya tampung 50 ton. Gudang didirikan 
lebih tinggi dari dasar permukaan tanah sehingga tetap menjaga permukaan lantai tetap kering. Pakan yang disimpan di dalam gudang disusun dengan ketinggian tumpukan $15-20$ karung.

\section{Pengendalian Persediaan Pakan Ayam di Rajowwatl Feed Centre}

Jumlah persediaan yang diadakan untuk menjaga kelancaren proses produksi (penjualan) tentang berapa besar akan dilakukan pemesanan tergantung pada estimasi permintaan dan laporan dari bagian gudang.

\section{Titik Pemesanan Pakan Kembali}

Kebutuhan persediaan pakan harus menyesuaikan dengan jenis dan jumlah yang terdapat di gudang. Jika sekiranya jumlah pakan untuk suatu jenis tertentu berada pada kondisi tinggal sedikit, maka harus dilakukan pemesanan kembali. Titik pemesanan kembali (Reorder line/ $R O L$ ) yaitu jumlah pakan ayam yang tersisa di gudang harus mampu untuk mencukupi permintaan selama dila-kukan pemesanan pakan yang baru (masa tenggang). Tujuannya untuk men- cegah terjadinya kekurangan persediaan (siock out).

Pada kebutuhan penjuaian tahun 2006, dalam mengatasi kekurangan stok Rajawali harus menentukan titik pemesanan kembali. Kebutuhan satu mingga minimal $247.394 \mathrm{~kg}$. Ketika jumlah pakan yang tersisa di gudang tinggal $247.394 \mathrm{~kg}$ maka Rajawali harus memesen kembali. Namun pemesanan pakan dilakukan pada setiap hari dengan jumlah pemesanan $35,342 \mathrm{~kg}$ per hari untuk memenuhi kebutuhan 1 minggt.

\section{Sistem Pengendalian Pemesanan Persediana Pakan \\ Pemesanan ditentukan berdasar- kan jumlah persediaan pakan pada tingkat tertentu yang merupakan batas waktu dilakukannya pemesanan yang disebut order point/reorder point.}

\section{Tahapan Proses Peagendalian Persedian di Rajawali Feed Centre}

a. Proses Pengambilan Keputusan Melakukan Pemesanan Pakan

Jumlah pembelian pakan ke pabrik itu sangat ditentukan oleh estimasi tenaga di lapangan, yang dikaitkan dengan stok pakan terakhir di gudang disaat order barang.

Tabel 3. Jenis Pakan Ayam yang Dijual di Rajawali Feed Centre

\begin{tabular}{clcl}
\hline No & $\begin{array}{c}\text { Jenis Pakan } \\
\text { Ayam }\end{array}$ & $\begin{array}{c}\text { Berat Per } \\
\text { Karung (KG) }\end{array}$ & \multicolumn{1}{c}{ Kegunaan } \\
\hline 1 & B 511 & 50 & Broiler umur 1 minggu \\
2 & B 512 & 50 & Broiler umur 2 minggu keatas \\
3 & B 311 & 50 & Broiler awal \\
4 & 124 & 50 & Layer masa produksi \\
5 & B 124 & 50 & Layer masa produksi \\
6 & 511 & 50 & Broiler dan Layer tahap uwal \\
7 & 311 & 50 & Layer awal dan Broiler awal \\
8 & 321 & 50 & Layer awal \\
9 & 122 & 50 & Layer grower (tahap pertumbuhan) \\
10 & 126 & 50 & Layer masa produksi \\
\hline
\end{tabular}


Pihak perusahaan berusaha untuk mengatur sirkulasi stok dengan jumlah $247.394 \mathrm{~kg}$ perminggu, kemungkinan permintaan pelanggan mampu terpenuhi. Jika terjadi kekurangan maka persentase yang tidak terlalu signifikan.

\section{b. Proses Pemesanan Pakan}

Untuk sistem pembayaran pakan yang dipesan ke pabrik menggunakan sistem cost before delivery (CBD). Perusahaan mengorder setiap hari, jika mengorder terlalu besar bisa melebihi kapasitas gudang, dan juga masalah parkir dan keamanan, dan juga agar cashflow tidak terganggu. Tanggung jawab pabrik hanya sampai pada mobil pengangkut. Untuk proses pengangkutan pakan dari Medan ke Padang adalah tanggung jawab pembeli (Rajawali).

\section{c. Proses Penanganan Pakan yang Datang}

Sebelum pakan yang baru datang maka dilakukan perencanaan barang akan masuk ke gudang. Proses bongkar di gudang hanya dilakukan pada jam kerja. Pengangkutan hanya bertanggung jawab mengantar pakan sampai ke pintu gudang. Biaya bongkar gudang, biaya-biaya yang timbul untuk proses bongkar muat ditanggung oleh Rajawali Feed Centre.

\section{d. Proses Penyimpanan Pakan di Gudang \\ Batas maksimal pakan yang bisa} disimpan yang diterapkan di gudang, adalah satu bulan setelah barang keluar dari pabrik. Perjalanan pengangkutan butuh waktu satu minggu, maka pakan yang disimpan digudang paling lama adalah tiga minggu. e. Proses Distribusi Pakan

Sistem yang diterapkan adalah First In First Out (FIFO) karena pakan mudah rusak.

\section{E. Jumlah Pemesanan Ekonomis Pakan Ayam di Rajawali FC}

Pada Tabel 4 bisa dilihat proyeksi kebutuhan pakan tahun 2006 dengan Metode Least Square dari tahun 2002 sampai dengan tahun 2005 .

Jumlah kebutuhan pakan ayam untuk tahun 2006 (dilambangkan dengan A) di Rajawali Feed Centre setelah di hitung dengan metode Least Square tersebut adalah 12.900 ton atau $12.900 .000 \mathrm{~kg}$. Harga pakan rata-rata per kilogram (dilambangkan $\boldsymbol{R}$ ) adalah Rp 3.315. Sehingga diperoleh total nilai pakan untuk kebutuhan pakan tahun 2006 adalah $R p$ 42.764.520.000, Biaya-biaya yang timbul karena adanya persediaan terdiri dari :

1. Biaya Pemesanan (Ordering Cost) dilambangkan $P$

a. Biaya Fax : Rp 10.000,- per order

b. Biaya Telepon : Rp 10.000 per order

c. Biaya Transfer Uang: Rp 30.000 per order

d. Biaya Pengangkutan: Rp 9.188 .920 per order

e. Biaya Bongkar : Rp 353.420 per order

Total biaya pemesanan/ordering cost (P) per pesanan adalah Rp 9.592.340.

2. Biaya Penyimpanan (Carrying Cost) dilambangkan $C$

a. Biaya Asuransi : Rp 0,10 per kg

b. Biaya Penyusutan : Rp 1,23 per $\mathrm{kg}$

c. Biaya Sewa Gudang : Rp 2 per $\mathrm{kg}$ 
d. Biaya Tenaga Gudang ; Rp 1 per $\mathrm{kg}$

e. Biaya Susun Barang : Rp 1 per $\mathrm{kg}$

f. Ongkos Muat : Rp 10 per kg

Total biaya penyimpanan adalah Rp 15,33 per kg.

\section{Jumlah Pemesanan Ekonomis}

Dari keterangan diatas dapat dihitung Jumlah Pemesanan Ekonomis / Economic Order Quantity (EOQ) sebagai berikut :

$$
N=\sqrt{\frac{2 A P}{R C}}
$$

dimana,

- Kebutuhan pakan ayam setahun (A) $=12.900 .000 \mathrm{~kg}$

- Biaya pemesanan $(\mathrm{P})$ per order = Rp 9.592.340

- Biaya penyimpanan (C) per $\mathrm{kg}=$ Rp 15,33

- Harga pakan rata-rata $(\mathrm{R})$ per $\mathrm{kg}=$ Rp 3.315.

$$
\begin{aligned}
& N=\sqrt{\frac{2(12.900 .000 \mathrm{~kg})(\operatorname{Rp} .9 .592 .340)}{(R p .3 .315)(R p .15,33)}} \\
& N=\sqrt{\frac{247.482 .372 .000 .000}{50.818,9}}
\end{aligned}
$$

$N=\sqrt{4.869 .888 .408}$

$N=69.784,5 \mathrm{~kg}=69.784 \mathrm{~kg}$

per pesanan, atau

$N=69,784$ ton per pesanan

Untuk Menghitung Jumlah Pemesanan Ekonomis (EOQ) untuk masing-masing jenis pakan diperoleh dengan cara mengalikan antara EOQ total pakan per pesanan dengan persentase kebutuhan setiap jenis pakan (cara menghitung persentase dapat dilihat pada Tabel 5).

\section{Jumlah Melakukan Pemesanan Dalam Satu Tahun}

Untuk menghitung Jumlah Order Selama Satu Tahun :

$N=\frac{12.900 .000 \mathrm{~kg}}{69.784 \mathrm{~kg}}$

$N=184,8=185$ kali dalam setahun, atau

$N=\frac{365 \text { hari }}{185 \text { hari }}$

$N=1,97=2$ hari

Pemesanan pakan ayam ke pabrik dilakukan sebanyak 185 kali dalam setahun atau sekitar 2 hari sekali melakukan pemesanan.

Tabel 4. Perkiraan Kebutuhan Penjualan Pakan Ayam Tahun 2006.

\begin{tabular}{clr}
\hline No & \multicolumn{1}{c}{ Jenis Pakan } & Perkiraan Penjualan Tahun 2006 (Ton) \\
\hline 1 & B 511 & 4.410 \\
2 & B 512 & 210 \\
3 & B 311 & 252 \\
4 & 124 & 4.866 \\
5 & B 124 & 972 \\
6 & 511 & 270 \\
7 & 311 & 318 \\
8 & 321 & 120 \\
9 & 122 & 888 \\
10 & 126 & 594 \\
\hline & Total & 12.900 \\
\hline
\end{tabular}


Tabel 5. Jumlah Pemesanan Ekonomis Setiap Jenis Pakan Per Order

\begin{tabular}{|c|c|c|c|c|c|}
\hline \multirow[t]{2}{*}{ No } & \multirow{2}{*}{$\begin{array}{l}\text { Jenis } \\
\text { Pakan }\end{array}$} & \multirow{2}{*}{$\begin{array}{c}\text { EOQ Total } \\
\text { Per Order (KG) }\end{array}$} & \multirow{2}{*}{$\begin{array}{c}\text { \% Kebututhan } \\
\text { Setiap Jenis Pakan }\end{array}$} & \multicolumn{2}{|c|}{ EOQ Setiap Jenis Pakan } \\
\hline & & & & $\mathrm{Kg}$ & Ton \\
\hline 1 & B 511 & 69.784 & 34,18 & $23.852,17$ & 23,852 \\
\hline 2 & B 512 & 69,784 & 1,63 & $1.137,48$ & 1,137 \\
\hline 3 & B 311 & 69.784 & 1,95 & $1.360,78$ & 1,361 \\
\hline 4 & 124 & 69.784 & 37,72 & $26.322,52$ & 26,322 \\
\hline 5 & B 124 & 69.784 & 7.53 & $5.254,73$ & 5,255 \\
\hline 6 & 511 & 69.784 & 2,09 & $1,458,48$ & 1,458 \\
\hline 7 & 311 & 69.784 & 2,46 & $1.716,68$ & 1,717 \\
\hline 8 & 321 & 69.784 & 0,93 & 648,99 & 0,649 \\
\hline 9 & 122 & 69.784 & 6,88 & $4.801,14$ & 4,801 \\
\hline 10 & 126 & 69.784 & 4,60 & 3.210 .06 & 3,210 \\
\hline \multicolumn{2}{|r|}{ Jumlah } & & 99,97 & $69.763,03$ & 69,762 \\
\hline
\end{tabular}

\section{Total Biaya Pertahun}

Untuk menghitung Total Biaya (Total Cost) yang harus dikeluarkan dalam satu tahun yaitu:

TC $=$ Biaya Pemesanan Pertahun + Biaya Penyimpanan Pertahun.

a. Biaya pernesanan pertahun

Adapun biaya pemesanan per tahun diperoleh dengan mengalikan jumlah kebutuhan penjualan tahun 2006 dengan biaya pemesanan per pesanan, kemudian dibagi dengan tingkat pemesanan.

Biaya pemesanan pertahun $=\frac{A x P}{N}$

Biaya pemesanan pada setiap pemesanan di Rajawali terdiri dari :

1. Biaya pemesanan yang besar jumlah pengeluarannya berdasarkan pada jumlah frekwensi pemesanan, yaitu :

\begin{tabular}{ll} 
Biaya telepon & $R p 10.000$ \\
Biaya fax & $R p 10.000$ \\
Biaya transfer uang & $R p 30.000$ \\
\hline Total setiap pernesanan & Rp50.000
\end{tabular}
2. Biaya pemesanan yang besar jumlah pengeluarannya berdasarkan jumlah pakan yang dipesan, yaitu:

Biaya pengangkutan

$=\operatorname{Rp} 260$ per $\mathrm{kg} \times 69.784 \mathrm{~kg}$

Biaya bongkar

$$
=\operatorname{Rp} 18.143 .840
$$

$=\mathrm{Rp} 10$ per $\mathrm{kg} \times 69.784 \mathrm{~kg}$

in $\mathrm{Rp} \quad 697.840$

Total setiap pemesanan

$$
=\text { Rp18.841.680 }
$$

Jadi total biaya pemesanan setiap pemesanan (P), untuk tingkat pemesanan $69.784 \mathrm{~kg}$ adalah Rp 18.891.680.

Untuk biaya pemesanan pertahun = AxP/N

$$
\begin{aligned}
& =\frac{(12.900 .000 \mathrm{~kg})(R p .18 .891 .680)}{69.784 \mathrm{~kg}} \\
& =\frac{243.702 .672 .000 .000}{69.784} \\
& =R p 3.492 .242 .806
\end{aligned}
$$

b. Biaya penyimpanan pertahun

Biaya penyimpanan di Rajawali Rp 15,33 per kg pakan ayam. Satu kali pakan masuk pada perhitungan EOQ jumlahnya 69.784 
$\mathrm{kg}$. Maka biaya penyimpanan satu kali pakan ayam masuk jumlahnya Rp1.069.788,72. Dalam satu tahun pakan akan masuk 185 kali ( atau 184,8 sebelum dibulatkan), jadi total biaya penyimpanan satu tahunnya adalah :

Biaya penyimpanan pertahun

$$
=\operatorname{Rp} 1.069 .788,72 \times 184,8
$$$$
=\operatorname{Rp} 197.696 .955
$$

Setelah diperoleh biaya pemesanan dan biaya penyimpanan untuk satu tahun. Maka dapat dihitung total biaya untuk tahun 2006. Pada tingkat pemesanan $70.608 \mathrm{~kg}$ setiap kali pemesanan, total biaya satu tahunnya adalah :

$$
\begin{aligned}
\mathrm{TC}= & \operatorname{Rp} 3.492 .242 .806+ \\
& \operatorname{Rp} 197.696 .955 \\
\mathrm{TC}= & \operatorname{Rp} 3.689 .939 .761 .
\end{aligned}
$$

\section{F.Perbandingan Jumlah Pemesanan yang dilakukan Rajawali Feed Centre}

Tingkat pemesanan pakan ayam yang dilakukan Rajawali untuk memenuhi kebutuhan penjualan tahun 2006 adalah $35,342 \mathrm{~kg}$ setiap kali melakukan pemesanan. Pada tingkat tersebut, Rajawali harus melakukan 365 kali pemesanan dalam setahun, atau setiap hari melakukan pemesanan.

Total Biaya tahun 2006 yang akan dikeluarkan Rajawali pada tingkat pemesanan $35.342 \mathrm{~kg}$ per pesanan adalah :

$\mathrm{TC}=$ Biaya pemesanan pertahun + Biaya penyimpanan pertahun.

1. Biaya pemesanan pertahun

Biaya pemesanan di Rajawali terdiri dari :

a. Biaya pemesanan yang besar jumlah pengeluarannya berdasarkan jumlah frekwensi pemesanan. Satu kali pemesanan jumlahnya Rp. 50.000 . b. Biaya pemesanan yang besar jumiah pengeluarannya berdasarkan jumlah pakan yang dipesan, pada tingkat pernesanan 35.342 $\mathrm{kg}$, besar biaya pemesanan ini yaitu :

Biaya pengangkutan =

Rp $260 \times 35.342 \mathrm{~kg}=$

$$
\begin{array}{ll}
\text { Biaya bongkar } & = \\
\operatorname{Rp~} 10 \times 35.342 \mathrm{~kg} & = \\
& \operatorname{Rp} 353.420
\end{array}
$$

Total setiap pemesanan

Rp 9.542 .340

Jadi biaya pemesanan setiap pemesanan (P), pada tingkat pemesanan $35.693 \mathrm{~kg}$, jumlahnya yaitu :

$$
\begin{aligned}
& \mathrm{P}=\mathrm{Rp} \cdot 50.000+\mathrm{Rp} \cdot 9.542 .340 \\
& \mathrm{P}=\mathrm{Rp} \cdot 9.592 .340 \\
& \text { Untuk biaya pemesanan pertahun }
\end{aligned}
$$

$$
=\frac{A x P}{N}
$$$$
=\frac{(12.900 .000 \mathrm{~kg})(\operatorname{Rp} .9 .592 .340)}{35.342 \mathrm{~kg}}
$$

$=\frac{123.741 .186 .000 .000}{35.342}$

$=R p \cdot 3.501 .250 .241$

2. Biaya penyimpanan pertahun

Pada tingkat pemesanan Rajawali, satu kali pakan ayam masuk jumlahnya $35.342 \mathrm{~kg}$. Biaya penyimpanan $\mathrm{Rp} 15,33$ per $\mathrm{kg}$ pakan ayam. Jadi besarnya biaya penyimpanan satu kali pakan masuk ke gudang adalah $\mathrm{Rp} 541.792,8$. Dalam satu tahun, pakan ayam akan masuk sebanyak 365 kali. Jadi biaya penyimpanan satu tahun yaitu :

Biaya penyimpanan setahun

$$
\begin{aligned}
& =\operatorname{Rp} 541.792,8 \times 365 \\
& =\operatorname{Rp} 197.754 .394
\end{aligned}
$$

Setelah diketahui biaya pemesanan pertahun dan penyimpanan pertahun, maka total biaya persediaan 
pakan ayam yang akan dikeluarkan Rajawali untuk tahun 2006 adalah :

$\mathrm{TC}=\mathrm{Rp} 3.501 .250 .241+$ Rp 197.754 .394

$\mathrm{TC}=\mathrm{Rp} 3.699,004.635$.

Dari hasil yang diperoleh tersebut di atas, terlihat bahwa pada tingkat pemesanan Rajawali, untuk memenuhi kebutuhan penjualan pakan ayam tahun 2006, jumlah pemesanan yang akan dilakukan adalah sebesar $35.342 \mathrm{~kg}$ setiap kali melakukan pemesanan. Jumlah pemesanan yang harus dilakukan dalam setahun 365 kali atau setiap hari harus melakukan pemesanan. Pada tingkat pemesanan tersebut, Rajawali harus mengeluarkan biaya yang timbul karena adanya persediaan tersebut dalam setahun (tahun 2006) adalah sebesar Rp 3.699.004.635.

Sedangkan pada perhitungan menggunakan rumus EOQ, untuk memenuhi kebutuhan penjualan tahun 2006 , tingkat pemesanan pakan ayam adalah $69.784 \mathrm{~kg}$ setiap kali memesan. Pada tingkat tersebut, jumlah pemesanan yang perlu dilakukan dalam setahun adalah 185 kali atau setiap 2 hari sekali harus melakukan pemesanan. Pada tingkat pemesanan menurut hasil penelitian, total biaya yang harus dikeluarkan dalam tahun 2006 adalah sebesar Rp3.689.939.761. Pada Tabel 6 dapat dilihat perbandingan biaya persediaan antara Rajawali dengan hasil penelitian, yaitu perbandingan biaya pemesanan per- tahun dan biaya penyimpanan pertahun yang harus dikeluarkan selama tahun 2006 .

Dari total biaya yang harus dikeluarkan antara tingkat pemesan Rajawali dengan tingkat pemesanan basil penelitian, terlihat bahwa pada tingkat pemesanan pakan ayam menurut hasil penelitian, total biaya yang dikeluarkan lebih kecil jika dibandingkan total biaya yang harus dikeluarkan pada pemesanan pakan ayam Rajawali. Artinya pemesanan persediaan pakan ayam menurut hasil penelitian dapat lebih mengefisienkan biaya, yakni sebesar Rp 9.064 .874 dalam tahun 2006.

Efisiensi tersebut terjadi karena jumlah melakukan pemesanan dalam satu tahun menjadi lebih sedikit, pada saat pemesanan ditingkatkan menjadi $69.784 \mathrm{~kg}$ setiap pemesanan. Semula pada tingkat pemesanan $35.342 \mathrm{~kg}$, jumlah pernesanan setahun sebanyak 365 kali. Namun ketika pada tingkat pemesanan $69.784 \mathrm{~kg}$, jumlah pemesanan yang perlu dilakukan dalam setahun hanya 185 kali saja. Berkurangnya jumlah pemesanan tersebut tentunya dapat mengurangi biaya pemesanan yang timbul dalam satu tahun.

Adapun biaya yang terlihat mengalami efisiensi adalah biaya pemesanan yang besarnya jumlah pengeluarannya tergantung pada banyaknya melakukan pemesanan.

Tabel 6. Perbandingan Biaya Persediaan Rajawali dengan Hasil Penelitian (2006)

\begin{tabular}{|c|c|c|c|}
\hline No & Jenis Biaya Persediaan & $\begin{array}{c}\text { Perhitungan } \\
\text { Rajawali (Rp) }\end{array}$ & $\begin{array}{c}\text { Perhitungan EOQ } \\
(\mathrm{Rp})\end{array}$ \\
\hline 1 & Biaya Pemesanan pertahun & 3.501 .250 .241 & 3.492 .242 .806 \\
\hline 2 & Biaya Penyimpanan pertahun & 197.754 .394 & 197.696 .955 \\
\hline & TOTAL & 3.699 .004 .635 & 3.689 .939 .761 \\
\hline
\end{tabular}


Biaya ini terdiri dari biaya telepon, biaya faxmail dan biaya transfer uang. Biaya ini tidak dipengaruhi oleh banyaknya jumlah pakan yang dipesan. Walaupun tingkat pemesanan ditingkatkan, biaya ini tidak mengalami perubahan. Akan tetapi apabila frekwensi pemesanan dikurangi, maka biaya pemesanan ini akan dapat mengalami pengurangan pula.

Adapun biaya pengangkutan; biaya bongkar dan semua biaya yang termasuk dalam biaya penyimpanan, dalam satu tahun biaya ini jumlahnya tetap walaupun jumlah melakukan pemesanan dikurangi. Hal ini dikarenakan biaya-biaya tersebut, tidak dipengaruhi oleh banyaknya jumlah melakukan pemesanan, akan tetapi dipengaruhi oleh jumlah pakan ayam yang dibutuhkan untuk penjualan dalam satu tahun. Jadi biaya ini, jumlahnya akan selalu tetap sebesar jumlah pakan yang akan dibutuhkan dalam tahun 2006 , selama tingkat biaya yang telah ditetapkan tidak mengalami perubahan.

\section{Kesimpulan}

Dari hasil penelitian ini dapat disimpulkan bahwa :

1. Proses pengendalian persediaan pakan ayam yang dilakukan oleh Rajawali pada kenyataannya mampu untuk mengendalikan jalannya proses produksi (penjualan) pakan ayam di dalam usahanya secara lancar dan teratur.

3. Adanya suatu tingkat pemesanan persediaan pakan ayam yang lebih ekonomis daripada pemesanan yang dilakukan oleh pihak perusahaan. Tingkat pemesanan tersebut yaitu $69.784 \mathrm{~kg}$ setiap kali pemesanan dengan fekwensi pemesanan 2 hari sekali. Efisiensi biaya yang terjadi $\mathrm{Rp} 9.064 .874$ dalam tahun 2006.

4. Biaya yang mengalami efisiensi yaitu biaya pemesanan yang besarnya jumlah yang harus dikeluarkan dipengaruhi oleh jumlah melakukan pemesanan. Biaya tersebut terdiri dari biaya telepon, biaya faxmail dan biaya transfer uang. Sedangkan biayabiaya lainya semua bersifat tetap per tahun.

\section{Daftar Pustaka}

Assauri, S, 1999. Manajemen Produksi Dan Operasi. LPFEUL, Jakarta.

Battersby, A, 1976. Penuntun Pengendalian Persediaan. Erlangga, Jakarta.

Buffa, E.S, 1993. Manajemen Produksi / Operasi, Edisi 7. Erlangga, Jakarta.

Handoko, H.T, 1984. Dasar-Dasar Manajemen Produksi Dan Operasi. BPFE-UGM, Yogyakarta.

Ichsan, W.M, 2003. Membuat Pakan Ayam Ras Pedaging. Agromedia Pustaka, Jakarta.

Johns, D.T. dan H.A. Harding, 1996. Manajemen Operasi. Pustaka Binaman Pressindo, Jakarta.

Sukanto, dan Indriyo, 1976. Manajemen Produksi. BPFEUGM, Yogyakarta.

Winarti, dan Djoko, S, 1992. Manajemen Produksi. Univeritas Terbuka, Jakarta. 
$\begin{array}{ll}\text { Alamat Korespondensi: } & \text { Rahmat Syafriardi, SP, MM } \\ \text { Jurusan Produksi Ternak } \\ \text { Fakultas Peternakan Universitas Andalas } \\ \text { Kampus Limau Manis Padang }\end{array}$

Artikel diterima 13 September 2006, disetujui 10 Oktober 2006 